\title{
Evaluation of the Characteristic of Adsorption in a Double-Effect Adsorption Chiller with FAM-Z01
}

\author{
Takehiro Esaki*, Noriyuki Kobayashi, Takayuki Matsuda \\ Department of Chemical Engineering, Nagoya University, Nagoya, Japan \\ Email:*esaki@energy.gr.jp
}

How to cite this paper: Esaki, T., Kobayashi, N. and Matsuda, T. (2016) Evaluation of the Characteristic of Adsorption in a DoubleEffect Adsorption Chiller with FAM-Z01. Journal of Materials Science and Chemical Engineering, 4, 8-19.

http://dx.doi.org/10.4236/msce.2016.410002

Received: August 19, 2016

Accepted: October 7, 2016

Published: October 10, 2016

Copyright $\odot 2016$ by authors and Scientific Research Publishing Inc. This work is licensed under the Creative Commons Attribution International License (CC BY 4.0).

http://creativecommons.org/licenses/by/4.0/

\begin{abstract}
Here, we propose a double-effect adsorption chiller with a zeolite adsorbent (FAM-Z01) for utilization of waste heat. The FAM-Z01 adsorbent has the potential to recover waste heat in low temperatures ranging from 353 to $333 \mathrm{~K}$ and shows good potential in the adsorption chiller in terms of the high cooling output. A doubleeffect adsorption chiller could provide a higher Coefficient Of Performance (COP) than that of a single-effect chiller. In this paper, we developed a measuring method for the amount of adsorption in the first and second adsorber in a double-effect adsorption chiller and measured the adsorption and desorption rate based on the volumetric method. We calculated the COP of the adsorption chiller with the quantity of adsorbent obtained in the experiment. In the experiments, the quantity of adsorbent in the first adsorber was $0.14 \mathrm{~g}-\mathrm{H}_{2} \mathrm{O} / \mathrm{g}$-Ads at the pressure $20 \mathrm{kPa}$ and a desorption temperature over $100^{\circ} \mathrm{C}$. The amount of adsorbent in the second adsorber was equal to that of the first adsorber. By analyzing the COP with the experimental results, the COP value was calculated to be over $1.0(-)$ at any desorption temperature. The COP of the double-effect cycle was higher than that of single-effect cycle.
\end{abstract}

\section{Keywords}

Adsorption Chiller, Double-Effect, FAM-Z01, Coefficient of Performance

\section{Introduction}

In response to increasing energy consumption since the Industrial Revolution, the amount of industrial waste heat has been rising. Energy-cascading technologies have been developed to save on energy consumption. In particular, the development of advanced technologies to utilize low-temperature heat energy below $373 \mathrm{~K}$ would be beneficial in terms of reducing waste heat emissions. Recently, adsorption chillers have been receiving much attention. The adsorption chiller is one of the most advanced 
pieces of equipment that has the potential to collect or upgrade waste heat at lowtemperatures. An adsorption chiller can store waste heat at temperatures less than 353 $\mathrm{K}$ and supply cooling energy at levels around $283 \mathrm{~K}$ [1]-[3]. Furthermore, the refrigerant used in adsorption chillers is water vapor, which is environment friendly. However, adsorption chillers have some issues that make them difficult for practical use.

The most significant problem is that the coefficient of performance (COP) per unit is considerably smaller than that of an absorption chiller. The COP of an adsorption chiller is less than 1.0. The maximum value is approximately 0.65 at $358 \mathrm{~K}$ for a regenerative heat source. Adsorption chillers have a realistic heat loss between the adsorption steps and desorption steps. This is because adsorption chiller was a batch type for a chiller cycle. A previous study of an adsorption chiller proposed a high adsorption capacity of adsorbent as well as designed an adsorber for a heat exchanger in a combined cycle. In this study, we pay attention to a double-effect adsorption chiller cycle.

Figure 1 shows a schematic diagram of the double-effect adsorption chiller cycle. Figure 2 shows a schematic diagram of the equilibrium line for a double-effect cycle. The double-effect adsorption chiller cycle comprises four adsorbers, A1, A2, B1, B2 (first adsorber A1, B1 and second adsorber A2, B2), an evaporator, a condenser, valves, and metallic tubes. In the adsorption step, the heat cooling output was obtained in the evaporator when $\mathrm{H}_{2} \mathrm{O}$ vapor moves to the adsorbers $\mathrm{A} 1, \mathrm{~A} 2$, and the vapor adsorber, FAM-Z01. In the desorption step, the FAM-Z01, in the first adsorber B1, desorbs at a high heat source temperature. The desorbed $\mathrm{H}_{2} \mathrm{O}$ vapor from $\mathrm{B} 1$ moves and condenses

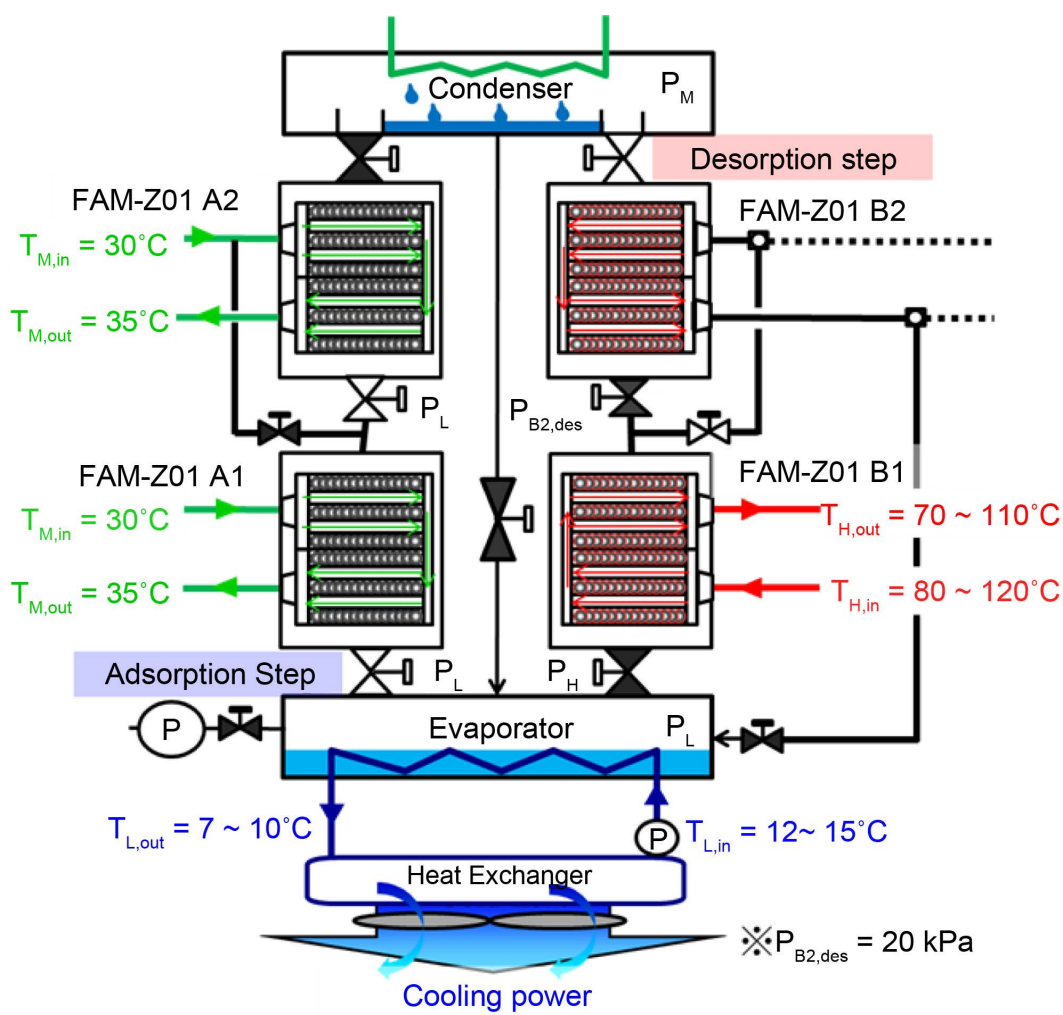

Figure 1. Schematic diagram of double-effect adsorption chiller cycle. 


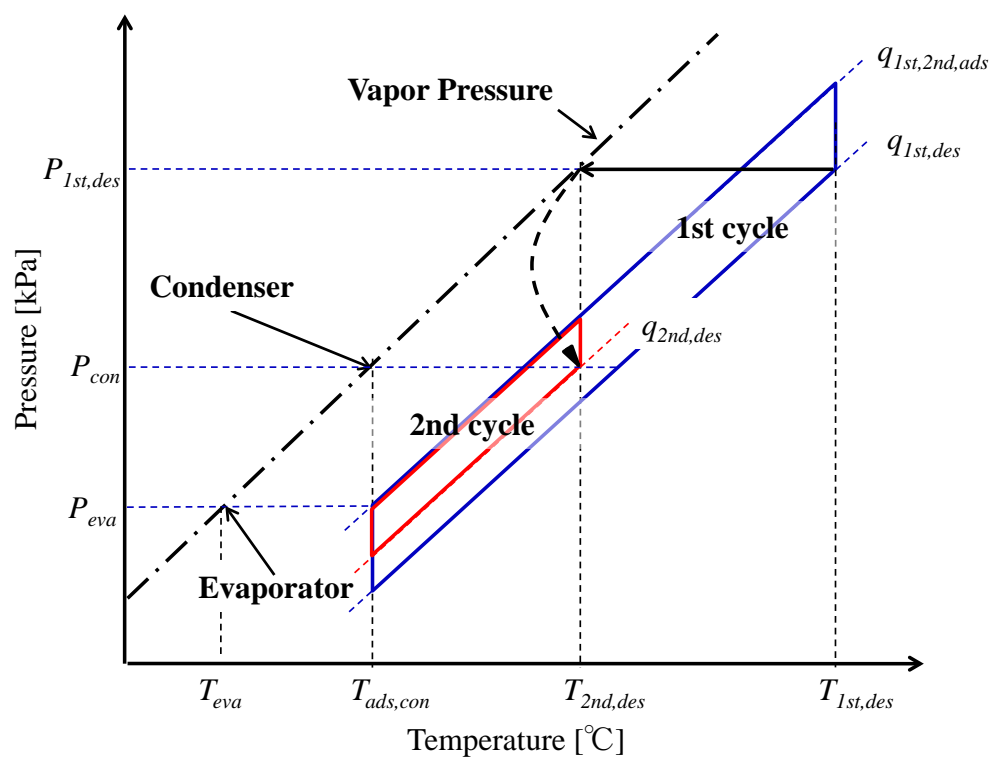

Figure 2. Equilibrium diagram of double-effect adsorption chiller cycle.

in the heat exchanger tube of the B2 adsorber. The FAM-Z01 on adsorber B2 is desorbed by condensation heat from B1 (first adsorber). Because the double-effect cycle obtained a heat cooling output from the first and second adsorber approaching the input desorption heat for the first adsorber, the cycle COP was expected to have much higher value than a single-effect cycle.

In general, the adsorption quantity was large because the desorption temperature was high in the adsorption chiller [4]. In a double-effect adsorption chiller cycle, it is desirable for the desorption temperature and pressure of the first adsorber to be high because the condensation heat of $\mathrm{H}_{2} \mathrm{O}$ vapor from the first adsorber was utilized for heat desorption in the second adsorber. The heat supply for the second adsorber was $\mathrm{H}_{2} \mathrm{O}$ vapor, not liquid.

In previous reports, the adsorbent for a double-effect adsorption chiller cycle has been silica gel. Recently, Marlinda published papers that refer to the feasibility of a double-effect adsorption chiller for numerical analysis. As a result, a double-effect cycle can be operated at the heat source temperature of $90^{\circ} \mathrm{C} \mathrm{[5]} \mathrm{[6].} \mathrm{In} \mathrm{addition,} \mathrm{The} \mathrm{COP} \mathrm{of}$ a double effect cycle is more than twice that of a single-effect cycle at a heat source temperature of $130^{\circ} \mathrm{C}$. Ashida has determined that $\mathrm{H}_{2} \mathrm{O}$ vapor desorbed from the first adsorber was condensed and the adsorbent for the second adsorber was heated and desorbed. The double-effect adsorption chiller cycle with silica gel functions is desired.

In this paper, adsorption isotherm and adsorption/desorption rate characteristics of a double-effect cycle with FAM-Z01 have been investigated. We have determined the behavior of the first and second adsorbers based on the assumption that a double effect cycle was operated. The volumetric method was employed to evaluate the influence of the desorption temperature and the adsorption bed thickness for the adsorption/ desorption rate. In the desorption step for the second adsorber, the amount of adsorption in the second adsorber, while $\mathrm{H}_{2} \mathrm{O}$ vapor was supplied, was determined using an 
estimate of the pressure and temperature of the first adsorber. We evaluated that the characteristic of COP with a double-effect adsorption chiller cycle was based on the amount of adsorption from experimental results.

\section{Experimental}

\subsection{Adsorbent}

FAM-Z01 of zeolite Adsorbent made by Mitsubishi Plastics, Inc. was selected for this study. FAM-Z01 was developed for adsorption chillers. The adsorption isotherms of water on FAM-Z01 are available for low temperature exhaust heat at approximately $60^{\circ} \mathrm{C}$.

In this experiment, the sample diameter was under $5 \mu \mathrm{m}$. Before the experiment, an adsorbent sample was out gassed at $90^{\circ} \mathrm{C}$ for $24 \mathrm{~h}$ inside vacuum.

\subsection{Experimental Apparatus}

This experiment for the evaluation of the amount of adsorbent and rate at which it adsorbs is measured using a static volumetric method. Figure 3 shows a schematic diagram of the experimental apparatus. The experimental apparatus consisted of an $\mathrm{H}_{2} \mathrm{O}$ vapor chamber, a reaction cell made from stainless steel, four valves, and a pressure gage (ULVAC CCMT-100, 1000 D), heaters, two Pt resistance temperature detector, the evaporators 1 and 2, and a vacuum pump. The experimental equipment was set up in a thermostat air box. The temperature of the $\mathrm{H}_{2} \mathrm{O}$ chamber as well as all the connecting pipelines was maintained at $60^{\circ} \mathrm{C}$ by a thermostat-controlled air box. The inner volume of the $\mathrm{H}_{2} \mathrm{O}$ chamber and reactor is $10,000 \mathrm{~mL}$ and $10 \mathrm{~mL}$, respectively. The $\mathrm{H}_{2} \mathrm{O}$ vapor pressure was changed, and the adsorption and desorption were measured by a pressure gage with a maximum uncertainty of $20 \mathrm{~Pa}$.

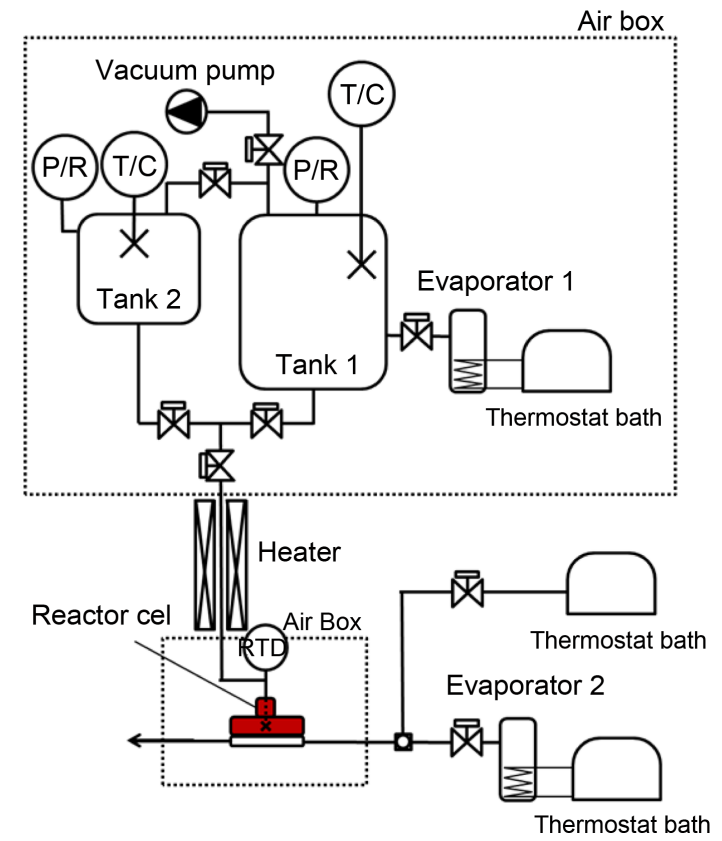

Figure 3. Schematic diagram of the experimental apparatus. 


\subsection{Experimental Procedure}

The main features of a different sample tested are recorded in Table 1. The samples were prepared with different masses with the aim to evaluate the effect of the thickness on the adsorption and desorption rates in the first and second adsorbers. In addition, the mass of the samples and the $\mathrm{H}_{2} \mathrm{O}$ chamber volume were selected specifically for each experiment. The mass of each sample was adjusted for the pressure fluctuation of the $\mathrm{H}_{2} \mathrm{O}$ chamber to maintain the adsorption value below 5\%. The thickness of the sample was measured by micrometer (Mitutoyo, DIGIMATIC MICROMETER, 293-140).

The adsorption and desorption rates with a double-effect adsorption cycle were evaluated based on the thickness of the adsorbent packed bed, so the thickness of the samples in this experiment were adjusted to change the packed bed area on the reaction cell for the remaining samples of the same weight.

First, the temperature of the reaction cell was set at $120^{\circ} \mathrm{C}$. The reaction cell and the $\mathrm{H}_{2} \mathrm{O}$ chamber were degassed for $12 \mathrm{~h}$. After that, all the valves were closed. Second, the $\mathrm{H}_{2} \mathrm{O}$ vapor evaporating from evaporator 1 was introduced to the $\mathrm{H}_{2} \mathrm{O}$ chamber, and the pressure was increased to the required pressure for adsorption. The temperature of the reaction cell was set at the appropriate adsorption temperature. The valve between the reactor and $\mathrm{H}_{2} \mathrm{O}$ chamber was opened, and the $\mathrm{H}_{2} \mathrm{O}$ vapor was introduced to the reactor. The pressure of the $\mathrm{H}_{2} \mathrm{O}$ chamber reduced along with the rate of adsorption. The pressure change was measured by a data-logger. The duration of time taken for the pressure of the $\mathrm{H}_{2} \mathrm{O}$ chamber to change was equal to the time required for adsorption equilibrium. Then, the valve was closed. Subsequently, the desorption step was initiated. The temperature of the reaction cell was raised to the desorption temperature. The pressure of the $\mathrm{H}_{2} \mathrm{O}$ chamber was either set to $20 \mathrm{kPa}$ (first adsorber) or $4.2 \mathrm{kPa}$ (second adsorber) with the use of a vacuum pump and evaporator 1 . The pressure of the $\mathrm{H}_{2} \mathrm{O}$ chamber was raised to correspond to the pressure required for desorption. The time required for the pressure of the $\mathrm{H}_{2} \mathrm{O}$ chamber to change occurred at the same time the desorption equilibrium was reached. When the rate of the first adsorber desorption was evaluated, the desorption heat was supplied by a medium heat at a high desorption temperature. However, when the rate of the desorption of the second adsorber was evaluated, the desorption heat was supplied by the condensation of the $\mathrm{H}_{2} \mathrm{O}$ vapor. The

Table 1. Experimental conditions.

\begin{tabular}{cccc}
\hline & Adsorption step & \multicolumn{2}{c}{ Desorption step } \\
\cline { 3 - 4 } & & 1 1st adsorber & 2nd adsorber \\
\hline Tank volume $[\mathrm{L}]$ & $1.07,1.40,1.75$ & 20 & 4.23 \\
Tank pressure $[\mathrm{kPa}]$ & & 0.12 & \\
Sample weight $[\mathrm{g}]$ & & $50-100,100-125,180-200$ & $60,58,56$ \\
Sample thickness $[\mu \mathrm{m}]$ & 30 & $120,110,100,90,80$ & Vapor \\
Adsorber temperature $\left[{ }^{\circ} \mathrm{C}\right]$ & Liquid & Liquid & \\
Heat supply type & & &
\end{tabular}


pressure of the $\mathrm{H}_{2} \mathrm{O}$ vapor provided by evaporator 2 was set at the first adsorber desorption pressure. When the desorption step was started, the $\mathrm{H}_{2} \mathrm{O}$ vapor was introduced to the reaction chamber with a reaction cell.

The amount of adsorption and the rates of desorption in this experiment were as follow:

$$
\begin{gathered}
\Delta n_{a d s, d e s}=n_{\text {initial }}-n_{\tan k}=\frac{\Delta P_{\tan k} \cdot V_{\tan k}}{R_{g} T_{\tan k}} \\
q_{\text {ads,des }}=\frac{\Delta n_{\text {ads, des }}}{n_{\text {theory }}}
\end{gathered}
$$

\section{Experimental Results and Discussion}

\subsection{Adsorption Step}

Figure 4 demonstrates the typical pressure variation of adsorption in different $\mathrm{H}_{2} \mathrm{O}$ chamber pressures. The pressure of the $\mathrm{H}_{2} \mathrm{O}$ chamber decreased with adsorption, but the value of the pressure change was very small compared to the initial $\mathrm{H}_{2} \mathrm{O}$ chamber pressure. Figure 5 shows the amount of adsorption compared to the duration of time at the adsorption temperature $30^{\circ} \mathrm{C}$. From the results, the amount of adsorption and the rate depends on the $\mathrm{H}_{2} \mathrm{O}$ pressure. Figure 6 shows the effect of the packed bed thickness for the adsorption rate at the $\mathrm{H}_{2} \mathrm{O}$ chamber pressure $1.0 \mathrm{kPa}$. The thickness was measured for each sample. From the experiment, the duration of time required to reach the adsorption $=0.1 \mathrm{~kg} / \mathrm{kg}$ was $46 \mathrm{~s}$ at $50-100 \mu \mathrm{m}, 164 \mathrm{~s}$ at $120-150 \mu \mathrm{m}, 772 \mathrm{~s}$ at $180-$ $200 \mu \mathrm{m}$, respectively. The time for 180 - $200 \mu \mathrm{m}$ was seventeen times longer than for 50 $100 \mu \mathrm{m}$. The adsorbent packed bed thickness was related to the thermal and mass transfer resistance. This is why the adsorbent packed bed thickness influenced the adsorption rate.

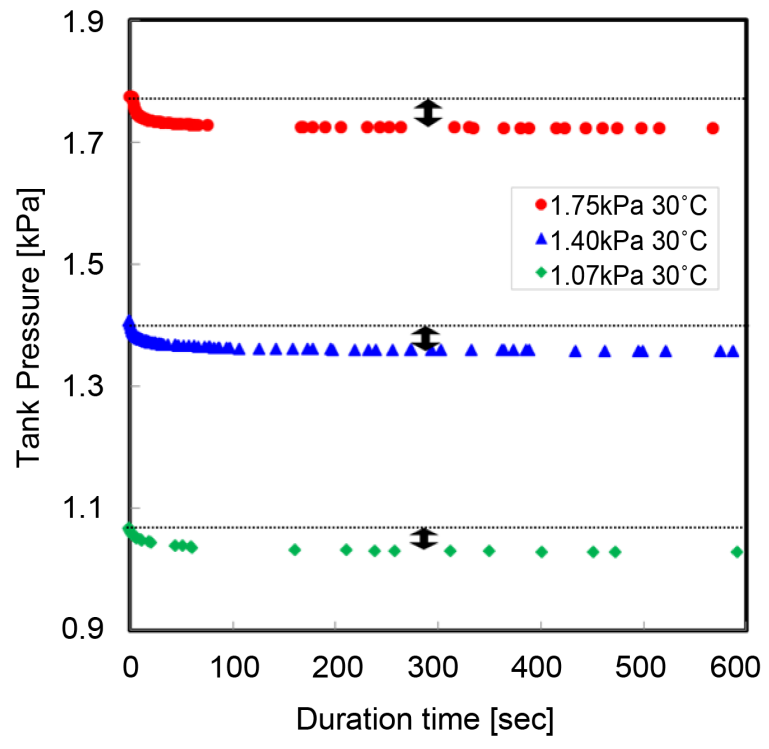

Figure 4. Experimental demonstration of tank pressure change. 


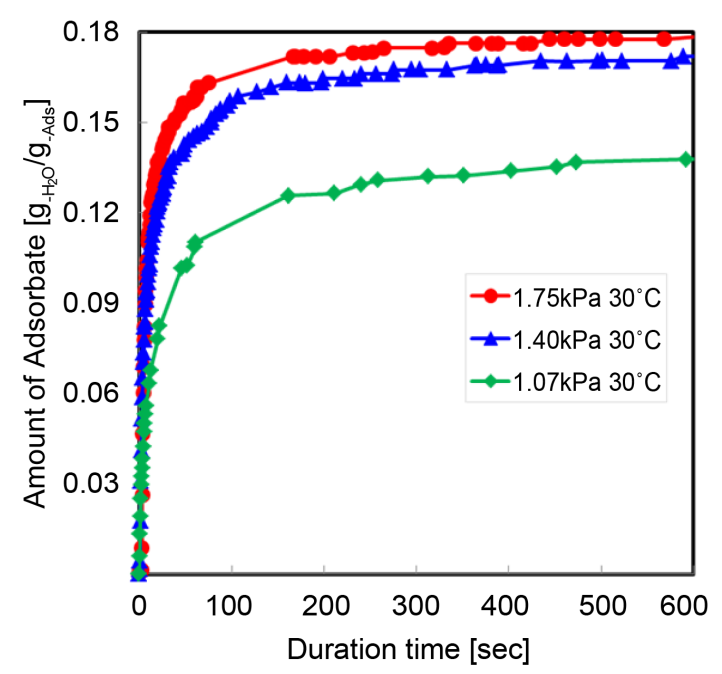

Figure 5. Typical time variation of the amount of adsorbate for different tank pressures.

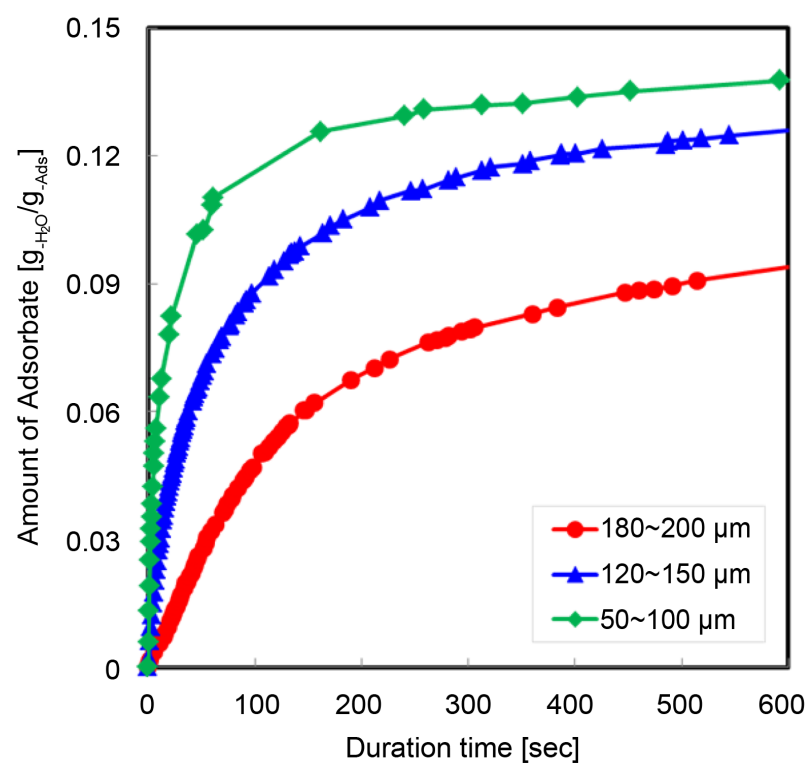

Figure 6. Typical time variation of the amount of adsorbate for different packed bed thickness.

\subsection{Desorption Step for the First Adsorber}

In this section, we evaluated the desorption rate for the first adsorber in a double-effect cycle. In this experiment, the adsorption step was conducted at $30^{\circ} \mathrm{C}, 1.0 \mathrm{kPa}$. Next, the $\mathrm{H}_{2} \mathrm{O}$ chamber pressure was set at $20 \mathrm{kPa}$, which was equal to saturated $\mathrm{H}_{2} \mathrm{O}$ vapor pressure at $60^{\circ} \mathrm{C}$. Figure 7 shows the effect of the desorption temperature on the desorption rate. From the experimental results, the desorption rate and the desorption equilibrium linearly increases with the desorption temperature. When the desorption temperature was over $100^{\circ} \mathrm{C}$, the amount of desorption was $0.14 \mathrm{~g} / \mathrm{g}$ at $100^{\circ} \mathrm{C}$ or more. It was expected that the dependency of the amount of desorption at temperatures over $100^{\circ} \mathrm{C}$ would be small, in addition, the input heat energy of a realistic heat for the first adsorber increased with temperature. Therefore, it was investigated that the desorption 
temperature for the first adsorber was $100^{\circ} \mathrm{C}$ in this study.

Figure 8 shows the desorption rates at $100^{\circ} \mathrm{C}$ under different packed bed thickness conditions. The temperature of the packed bed surface at this time was $50-100 \mu \mathrm{m}$. From the experimental results, the duration of time required for desorption equilibrium at $180-200 \mu \mathrm{m}$ was $100 \mathrm{sec}$. The duration of time required for desorption was rapid for all measured thickness conditions. The desorption temperature change with the duration of time was only $0.3^{\circ} \mathrm{C}$. The packed bed temperature was kept constant at $100^{\circ} \mathrm{C}$. In the desorption step for the first adsorber, the $\mathrm{H}_{2} \mathrm{O}$ vapor was rapidly desorbed from the adsorbent, and it was expected that the condensation heat energy was quickly supplied to the second adsorber.

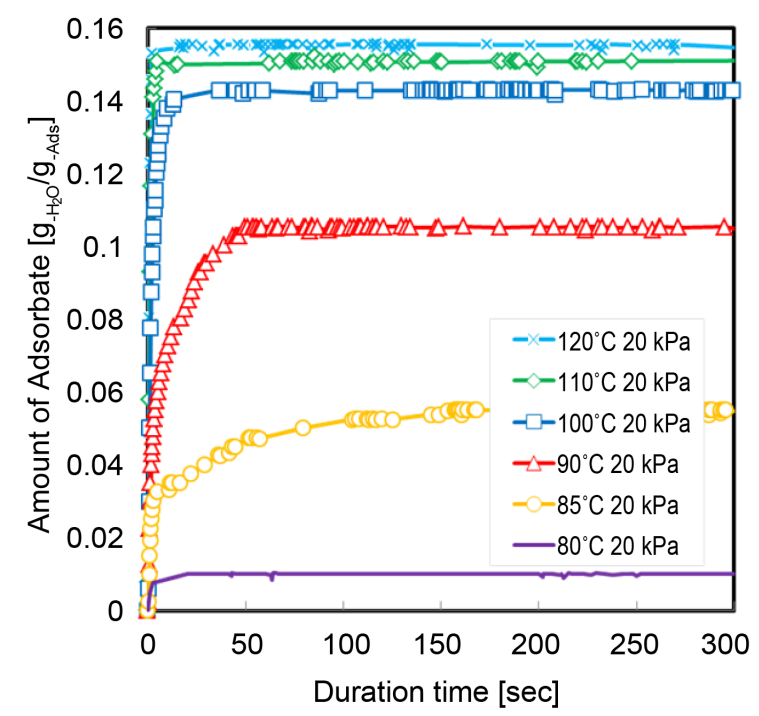

Figure 7. Typical time variation of the amount of adsorbate for different desorption temperatures at the first adsorber desorption step.

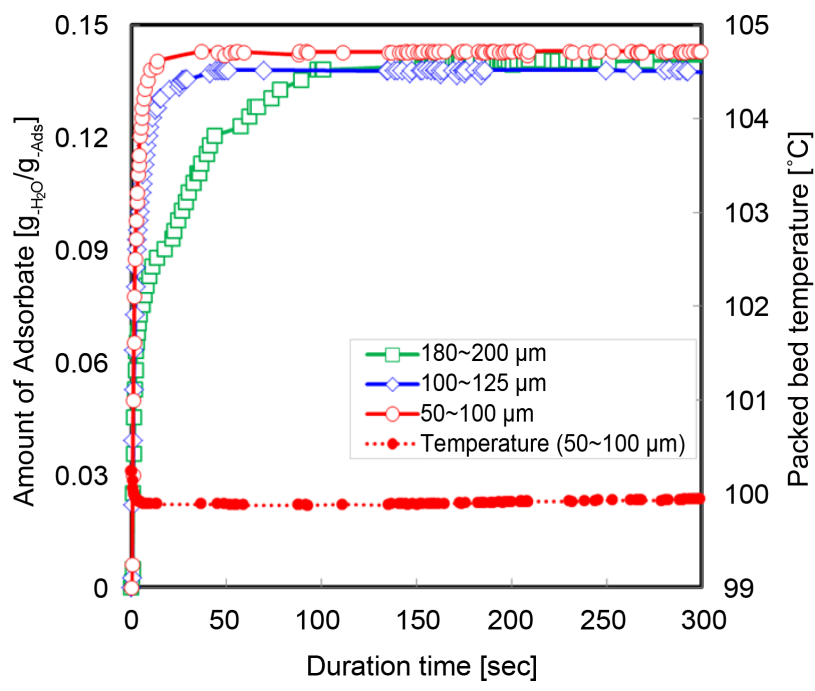

Figure 8. Typical time variation of the amount of adsorbate for different packed bed thicknesses at the first adsorber desorption step. 


\subsection{Desorption Step for the Second Adsorber}

After the adsorption step at $1.0 \mathrm{kPa}$ and $30 \mathrm{kPa}$ was completed, the valves were closed. The $\mathrm{H}_{2} \mathrm{O}$ chamber pressure was set at $4.2 \mathrm{kPa}$. The $\mathrm{H}_{2} \mathrm{O}$ vapor condensation heat was the desorption heat of the sample introduced to the reactor chamber. The $\mathrm{H}_{2} \mathrm{O}$ chamber could be set at any pressure by changing the evaporator 2 temperature. Figure 9 illustrates the amount of desorption with time as a function of the $\mathrm{H}_{2} \mathrm{O}$ pressure. From the measurement results in Figure 9, it can be seen that the amount of desorption and the rate was large because the $\mathrm{H}_{2} \mathrm{O}$ pressure was high. Figure 10 shows the amount of desorption with time at $20 \mathrm{kPa} \mathrm{H} \mathrm{H}_{2} \mathrm{O}$ vapor and liquid temperature of $60^{\circ} \mathrm{C}$, which was the saturated temperature at $20 \mathrm{kPa}$. From the measurement results in Figure 10, the

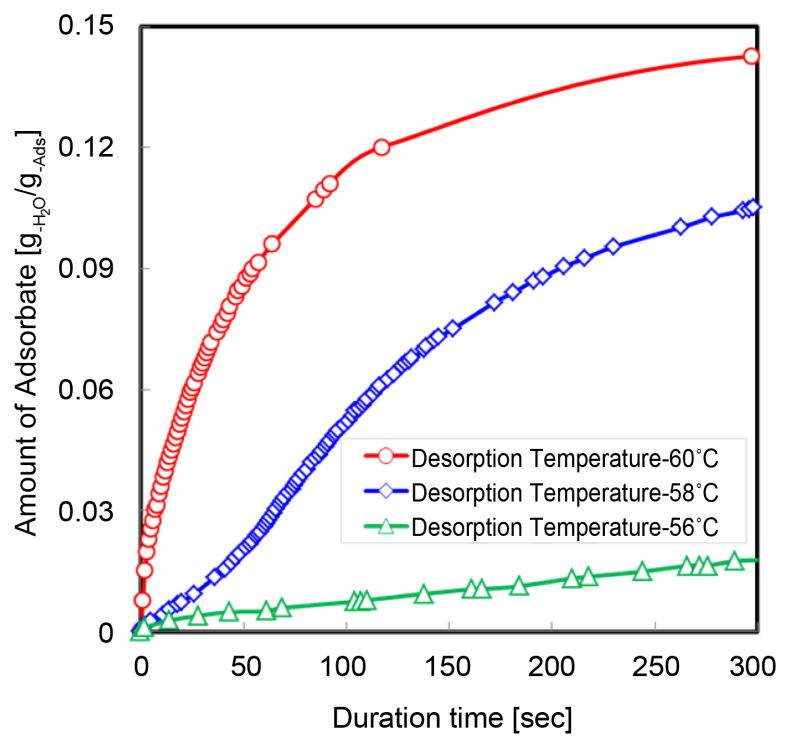

Figure 9. Typical time variation of the amount of adsorbate for different temperatures the second adsorber desorption step.

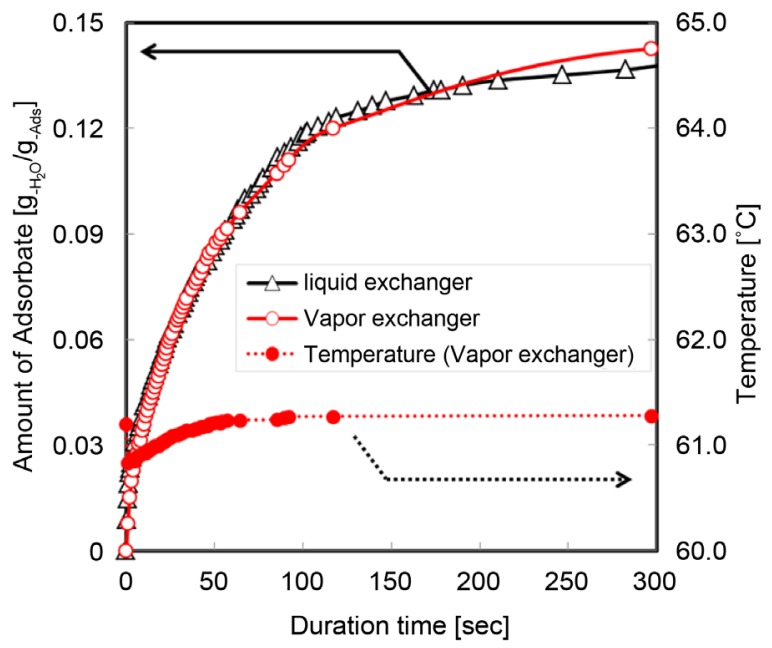

Figure 10. Typical time variation of the amount of adsorbate for different heat supply type at the second adsorber desorption step. 
desorption rate was same for both the supplied heat form conditions. The packed bed temperature change was under $0.5^{\circ} \mathrm{C}$ for the duration of time because the effect of the supplied heat form was very small.

Figure 11 shows the effect of the packed bed thickness on the desorption rate. From the experimental results, it can be seen that the desorption rate was large because the packed bed thickness was thin. In comparison with the first adsorber desorption step, it was revealed that the adsorbent packed bed thickness had an influence on the desorption rate. This is why the $\mathrm{H}_{2} \mathrm{O}$ vapor diffusion resistance on the adsorbent packed bed was different for $20 \mathrm{kPa}$ in the first adsorber desorption step and $4.2 \mathrm{kPa}$ on the second adsorber desorption step.

\section{Coefficient of Performance}

The coefficient of performance was calculated for a double effect adsorption cycle using the experimental quantity of adsorption and desorption. It was expected that the coefficient of performance for an adsorption chiller was capable of influencing realistic heat values for an adsorber heat exchanger. In this study, this value was investigated only for the adsorbent and the $\mathrm{H}_{2} \mathrm{O}$ refrigerant for realistic heat. The value referred to was from Mitsubishi Plastics, Inc [7]. Figure 12 illustrated the effect of the desorption temperature on the coefficient of performance. In addition, the coefficient of performance for a single-effect cycle was shown in Figure 12. The value of the coefficient of performance for double-effect cycle was 1.1 at $100^{\circ} \mathrm{C}$. The coefficient of performance on a singleeffect cycle at $60^{\circ} \mathrm{C}$ was 0.7 . It was expected that the realistic heat of the adsorbent and the $\mathrm{H}_{2} \mathrm{O}$ had an influence on the coefficient of performance for temperatures over $100^{\circ} \mathrm{C}$ and amount of adsorbent influenced the coefficient of performance for temperatures under $100^{\circ} \mathrm{C}$. The maximum value for the coefficient of performance on a double-effect cycle was 1.57 times higher than the value of a single-effect cycle.

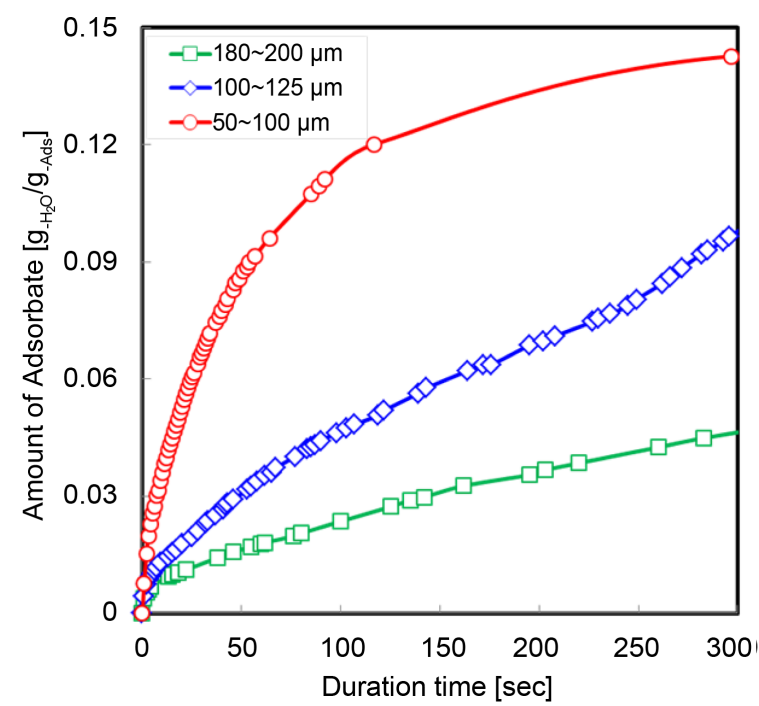

Figure 11. Typical time variation of the amount of adsorbate for different packed bed thicknesses at the second adsorber desorption step. 


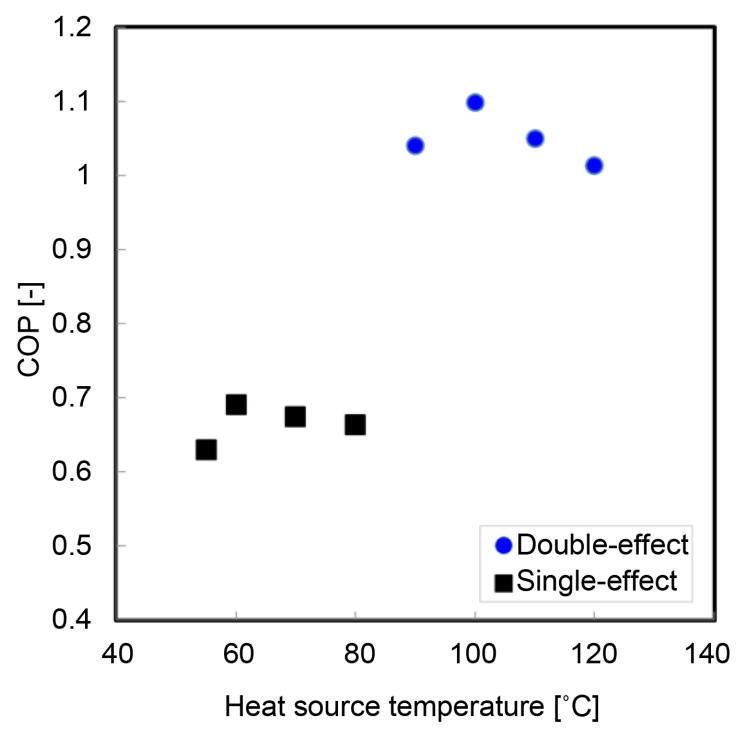

Figure 12. Effect of cycle type on the COP for adsorption chiller.

\section{Conclusions}

In this study, a double-effect adsorption chiller cycle with FAM-Z01 was evaluated. From the experimental study, we obtained the following results.

1) A double-effect adsorption chiller cycle can be operated at the desorption temperature of $100^{\circ} \mathrm{C}$. At this temperature, the quantity of adsorption was $0.14 \mathrm{~g} / \mathrm{g}$ for the first and the second adsorbers.

2) The COP was calculated from the quantity of adsorption for the experiment and the result was 1.1 at the desorption temperature $100^{\circ} \mathrm{C}$.

\section{References}

[1] Hong, S.W., Ahn, S.H., Chung, J.D., Bae, K.J., Cha, D.A. and Kwon, O.K. (2016) Characteristics of FAM-Z01 Compared to Silica Gels in the Performance of an Adsorption Bed. Applied Thermal Engineering, 104, 24-33.

http://dx.doi.org/10.1016/j.applthermaleng.2016.05.058

[2] Alahmer, A., Wang, X., Al-Rbaihat, R., Alam, K.C.A. and Saha, B.B. (2016) Performance Evaluation of a Solar Adsorption Chiller under Different Climatic Conditions. Applied Energy, 175, 293-304. http://dx.doi.org/10.1016/j.apenergy.2016.05.041

[3] Pan, Q.W., Wang, R.Z., Wang, L.W. and Liu, D. (2016) Design and Experimental Study of a Silica Gel-Water Adsorption Chiller with Modular Adsorbers. International Journal of Refrigeration, 67, 336-344. http://dx.doi.org/10.1016/j.ijrefrig.2016.03.001

[4] Hong, S.W., Kwon, O.K. and Chung, J.D. (2016) Application of an Embossed Plate Heat Exchanger to Adsorption Chiller. International Journal of Refrigeration, 65, 142-153. http://dx.doi.org/10.1016/j.ijrefrig.2016.02.012

[5] Marlinda, Miyazaki, T., Ueda, Y. and Akisawa, A. (2010) Static Analysis of Double Effect Adsorption Refrigeration Cycle Using Silica Gel/Water Pair. Transactions of the Japan Society Refrigerating and Air Conditioning Engineers, 27, 57-65.

[6] Marlinda, Uyun, A.S., Miyazaki, T., Ueda, Y. and Akisawa, A. (2010) Performance Analysis 
of a Double-Effect Adsorption Refrigeration Cycle with a Silica Gel/Water Working Pair. Energies, 3, 1704-1720. http://dx.doi.org/10.3390/en3111704

[7] Kakiuchi, H., Shimooka, S., Iwade, M., Oshima, K., Yamazaki, M., Terada, S., Watanabe, H. and Takewaki, T. (2005) Novel Water Vapor Adsorbent FAM-Z01 and Its Applicability to an Adsorption Heat Pump. Kagaku Kogaku Ronbunshu (Japan), 31, 361-364.

http://dx.doi.org/10.1252/kakoronbunshu.31.361

Submit or recommend next manuscript to SCIRP and we will provide best service for you:

Accepting pre-submission inquiries through Email, Facebook, LinkedIn, Twitter, etc. A wide selection of journals (inclusive of 9 subjects, more than 200 journals)

Providing 24-hour high-quality service

User-friendly online submission system

Fair and swift peer-review system

Efficient typesetting and proofreading procedure

Display of the result of downloads and visits, as well as the number of cited articles

Maximum dissemination of your research work

Submit your manuscript at: http://papersubmission.scirp.org/

Or contact msce@scirp.org 